\title{
Implementation and Supervision of the Professional Learning Community: Animation, Leadership and Organization of the Work
}

\author{
Yamina Bouchamma1, Lawrence Kalule1, Daniel April1, Marc Basque ${ }^{2}$ \\ ${ }^{1}$ Faculty of Education, Department of Foundations and Practices in Education, Laval University, Québec, Canada \\ ${ }^{2}$ Sector of Education, Kinesiology and Recreation, Moncton University, Edmundston, Canada \\ Email: yamina.bouchamma@fse.ulaval.ca
}

Received 17 July 2014; revised 8 August 2014; accepted 28 August 2014

Copyright (C) 2014 by authors and Scientific Research Publishing Inc.

This work is licensed under the Creative Commons Attribution International License (CC BY).

http://creativecommons.org/licenses/by/4.0/

(c) (i) Open Access

\begin{abstract}
This research, was based on a conceptual framework focusing on three main concepts: 1) shared leadership (encompassing the physical, human, and social dimensions) (Spillane et al., 2001a; 2001b); 2) instructional leadership; and 3) the professional learning community (PLC). Individual interviews were conducted with principals (P), vice principals (V-P), teachers $(T)$ and education consultants (EC) from schools in two Canadian provinces (Québec and New Brunswick) ( $\mathrm{N}=$ 39) to learn more regarding their practices within their respective PLCs in which they were either members or moderators. Thematic analyzes identified three major themes and sub-themes associated with each of them. Ensure 1) the physical capital 2) the human capital and 3) the social capital. Limitations and avenues for further research are discussed.
\end{abstract}

\section{Keywords}

Professional Learning Community, Leadership, Shared Leadership, Instructional Leadership, Professional Development

\section{Introduction}

In the wake of The Fifth Discipline: The Art and Practice of the Learning Organization (Senge, 1990), several authors (Leithwood \& Louis, 1998; Mitchell \& Sackney, 2000) have advocated that schools should become learning communities. Inspired by Wenger's study (1998) on communities of practice, research has focused on

How to cite this paper: Bouchamma, Y., Kalule, L., April, D., \& Basque, M. (2014). Implementation and Supervision of the Professional Learning Community: Animation, Leadership and Organization of the Work. Creative Education, 5, $1479-1491$. http://dx.doi.org/10.4236/ce.2014.516165 
the advantages of collective strength and intelligence and a shared vision to create and support sustainable reforms through rapid, flexible, and adaptable solutions (Senge, et al., 2000; Giles \& Hargreaves, 2006). This orientation basically centers on the benefits of collaborative effort for both the student and the teacher (Dufour \& Eaker, 1998; Hord \& Sommers, 2008) by developing their autonomy, by improving their behavior and professionalism (Tschannen-Moran, 2009; Wahlstrom \& Seashore-Louis, 2008), by encouraging practices that are more effective (Hord \& Sommers, 2008; Dufour \& Eaker, 1998; Vescio, Ross, \& Adams, 2008), and ultimately, by improving student learning and achievement (Butler et al., 2004).

Novel approaches to support teachers are rapidly evolving toward a culture of collective involvement. These new modes of pedagogical organization remain, however, relatively unknown and have not yet been fully conceptualized (Caldwell, 2007; Printy, 2004). With an accent on socioconstructivism, this type of supervision is based on the principle of a team approach that involves members belonging to the same field of expertise or professional practice (Bourhis \& Tremblay, 2004) who share these practices and representations in pursuing a common activity (Lave, 1988; Wenger, 1998). Interactions and discussions with peers, pivotal in this type of supervision (Lafortune \& Deaudelin, 2001), are achieved through concerted action initiatives that are both developed and implemented in a group rather than individually (Dionne, 2004; Lafortune \& Deaudelin, 2001; Lafortune \& Martin, 2004; Savoie-Zajc, 2004). Moreover, group leaders play an important role in this model. Specifically, the school principal is considered to have significant influence on the success of these PLCs (Mullen \& Hutinger, 2008; Clausen, Aquino, \& Wideman, 2009).

The two Canadian provinces involved in the present study, Québec and New Brunswick, attribute a specific instructional or pedagogical role to the school principal (respectively the Loisurl'instructionpublique and the Loisur l'éducation, LIP art. 96.12/Chapter E-1.12, 1997) Government of New Brunswick (1997).

The increasing importance bestowed on the pedagogical leader (PL) in schools has led researchers in Québec to challenge both stakeholders (educators and research domains) to take a closer look at the management of education activities, the influence of the principal's instructional leadership, and how this is applied (Brassard et al., 2004). If, in some areas, school teams and their principals have shown greater interest in the innovativeness of certain teachers whom they acknowledge and support (Deslauriers, 2008), according to Lusignan (2008), the pedagogical leader must go beyond these practices to not only enable and nurture a culture of collaboration among colleagues but also develop and encourage peer evaluations.

This principle of collegiality exists as much among the competencies listed in the teachers' manual (collaborate with the pedagogical team, cooperate with the school team, participate in teamwork, be committed individually and collectively) (Tarakdjian, 2008) as it does in that of the principal (supervise the educational practices of the members of the school's team, provide guidance for the work groups, encourage peer supervision, etc.) (Ministère de l'éducation du Loisiret du Sport (MELS), 2008). This type of support is in line with relevant studies confirming the effectiveness of group supervision (school principals, teachers, teaching consultants, etc.) within a process of change as a group rather than on an individual basis (Boucher \& Jenkins, 2004; Charlier, Dejean, \& Donnay, 2004; Dionne, 2004; Lafortune \& Martin, 2004; Savoie-Zajc, 2004). Teachers have stressed the importance of examining existing supervisory practices from the standpoint of both parties involved: the supervisor (principal, teacher-leader or other) and the person being supervised, namely, the teacher (Tarakdjian, 2008).

Since 1999, the New Brunswick Department of Education's Programme d'évaluation du personnel enseignant has been a standard procedure in its francophone schools (NBDE, 1999). This program is based on the following premise: the principal's supervision practices (pedagogical leadership) have a palpable and positive influence on teaching improvement, and consequently, on student achievement. They enable the teacher to constantly improve their skills and performance under the guidance of their principal, or department head in the case of high school (NBDE, 1999). On several occasions, the Department of Education has reminded its stakeholders of the importance of their pedagogical role, as shown in the province's Quality Learning Agenda (NBDE, 2002) and its introduction of When Kids Come First (NBDE, 2007) in which the creation of PLC is listed among the seven measures proposed to improve the level of student achievement, which mirrors the principle of collegiality expressed in the context in Québec.

\section{Review of the Literature}

\subsection{Instructional or Pedagogical Leadership}

Integrating the concept of PL in the minds of school administrators represents a lasting and effective action in 
successful schools (Hallinger, 2005). This instructional leadership involves the principal as much as it does the staff and implies accountability for both parties. Interestingly, this type of shared-responsibility leadership is predominant in effective schools. Studies on this subject have shown that the best student outcomes in core subjects are associated with an instructional form of leadership that not only makes student support and evaluation practices a priority (Anderson, 2008) but also encourages learning communities (Sillins \& Mulford, 2007; Hopkins, 2003).

Many studies have examined the effect of leadership on student learning and achievement (Hallinger \& Heck, 1996; Reynolds, Creemers, Stringfield, Teddlie, \& Schaffer, 2002; Waters, Marzano, \& McNulty, 2003). One group of authors deemed this effect to be second only to the teacher's effect (Leithwood, Day, Sammons, Harris, \& Hopkins, 2006; Leithwood et al., 2004). Studies on school success should be the cornerstone for any investigation on educational leadership and its effects on student outcomes, as leadership is a significant characteristic of effective schools. The leadership effect is considered to be indirect, with an impact stemming from multiple sources: staff motivation, dedication, and working conditions, distribution of power among all of the stakeholders involved in the school (Leithwood et al., 2006; Leithwood, 2007), and school organization and culture (Wahlstrom, 2004; Robinson et al., 2008; Leithwood et al., 2004; Leithwood \& Levin, 2005).

In their meta-analysis, Robinson et al. (2008) showed that the impact of instructional leadership on student outcomes was three to four times greater than that of transformational leadership. In a study by Anderson (2008) the best outcomes in mathematics and language were linked to instructional leadership, which was part of the school culture for years. Indeed, this type of leadership centered on providing evaluation and support for the students, with emphasis on the promotion of academic events in the community (Anderson, 2008).

\subsection{Using the PLC to Exercise Instructional Leadership}

The instructional leader is committed to ensuring that their school provides learning communities that enable their teachers to partake in learning activities, collaborations, and peer supervision so as to grow professionally by adopting the most effective practices out there (Hopkins, 2003). In high schools that use the PLC approach, the instructional leader promotes learning through the school's mission, objectives, culture, and structure, as well as through intellectual stimulation, individual support, and performance expectations (Sillins \& Mulford, 2007). Transforming schools with PLCs has become an interesting solution to the inherent challenges of individual guidance and supervision (Nolan \& Hoover, 2008).

\subsection{Impact}

PLCs have been shown to have many positive repercussions on both teachers and students (Cwikla, 2007). In addition to alleviating the teachers' sense of isolation (Hargreaves, 2003), reinforcing their professional identity (Newell Jones, 2006), and fostering a sense of belonging (Tremblay, 2005), PLCs contribute by consolidating their knowledge, practices, attitudes, and skills (Printy, 2004; Sackney, 2007). Principals are pivotal in the success of their PLC (Mullen \& Hutinger, 2008; Clausen, Aquino, \& Wideman, 2009). Formal leaders influence their organization and their teachers' beliefs with regard to their pedagogical skills. In the PLC setting, principals/department heads provide their teachers with professional growth opportunities (Printy, 2008). In fact, instructional leadership provides far greater development opportunities for their teachers, not to mention improving student achievement (Webb, 2005).

According to Hord and Sommers (2008), an effective school within the context of a PLC takes full advantage of 1) shared beliefs, values, and vision; 2) shared leadership and support; 3) collective learning and its applications; 4) nurturing conditions; and 5) shared personal practice.

How do PLCs operate? To summarize the vast amount of literature on the subject, we provide a synthesis in the form of a table for an easier read. Table 1 presents a synthesis of the principles, objectives and characteristics that encompass PLC development.

\subsection{Limited Research}

Over a decade ago, one author revealed a lack of data on how PLCs are established and maintained and how collaboration works in new situations (Fullan, 2000). Studies on PLCs have been criticized for not considering interpersonal, organizational, and group factors (Printy, 2004; 2008) as well guidance and supervision processes 
Table 1. Synthesis of principles objectives and characteristics that enable PLC development.

\begin{tabular}{|c|c|}
\hline Principles and objectives & Characteristics \\
\hline $\begin{array}{l}\text { 1. Mission, vision, values, and shared objectives } \\
\text { 2. Action orientation and experimentation } \\
\text { 3. A safe, nurturing environment for the members, which is } \\
\text { crucial to interactions and productivity } \\
\text { 4. Develop knowledge and learning. } \\
\text { SHARE: } \\
\text { 5. Common goals and a passion for the practice } \\
\text { 6. Normally tacit knowledge } \\
\text { 7. The same expertise or profession } \\
\text { 8. A common interest for a particular knowledge, experiences, }\end{array}$ & $\begin{array}{l}\text { 1. May form naturally in schools or be designed specifically for teachers' } \\
\text { professional development } \\
\text { 2. May be homogeneous or heterogeneous } \\
\text { 3. Different forms of collaboration: } \\
-\quad \text { horizontal (teachers at same level or teaching same subject) } \\
-\quad \text { and/or vertical (different levels or subjects) } \\
\text { 4. Various stages of development } \\
\text { 5. Requires several months before reaching maturity } \\
\text { 6. CP members regularly meet to discuss either virtually or in person }\end{array}$ \\
\hline
\end{tabular}

(Caldwell, 2007; Printy, 2004; Clausen et al., 2009), thus exposing themselves to political and practical repercussions (Caldwell, 2007; Hildreth \& Kimble, 2004). PLCs have become a promising vehicle for change in teacher professional development, despite certain challenges such as the gap between the ideal expressed in these studies and what really goes on in these learning communities (Clausen et al., 2009), and while past studies have described the types of activities proposed by instructional leaders, they fail to specifically address how they go about it (Coldren \& Spillane, 2007).

Research on the subject is thus incomplete, as the most complex reforms to help schools improve remain in a black box (Bogotch, Mirón, \& Biesta, 2007). The positive effect of effective leadership on student achievement is an established fact, however the way in which this leadership can make a difference, the degree of its effect, and the essential ingredients of an effective leadership have not yet been explored (Leithwood et al., 2004). Increasing our knowledge of how day-to-day leadership works will enable us to improve teachers' practices and ultimately provide insight on the impact of leadership on student achievement (Wahlstrom \& Louis, 2008).

\section{Conceptual Framework}

This study addressed three key concepts, namely shared leadership, instructional leadership, and the PLC. The model by Spillane et al. (2001a; 2001b) considers three dimensions: 1) the physical component, including such resources as money; 2) the human factor, such as the teacher's knowledge, skills, and expertise; and 3) the social component, involving the relationships between individuals resulting from such principles as trust and collaboration. These three interdependent dimensions demonstrate the need for a commitment by each stakeholder, a shared vision that translates to the creation of an environment that favors and nurtures teacher professional growth and PLC development. The participating individuals who share the activities are in an interdependent relationship with their environment. In this view, the context is the appropriate unit of analysis for the study of teacher practices (Spillane et al., 2001b).

\subsection{Instructional Leadership}

The instructional leader promotes teacher professional development in the form of "learning organizations" (Sillins \& Mulford, 2007) and considers their school to be a PLC (Hopkins, 2003). The leadership effect is indirect and its impact stems from many sources: the staff's motivation, dedication, and work conditions, the distribution of power among all of the actors involved in the school (Leithwood et al., 2006; Leithwood, 2007), and the school's organization and culture (Wahlstrom, 2004; Robinson et al., 2008; Leithwood et al., 2004; Leithwood \& Levin, 2005).

\subsection{The Professional Learning Community}

Principles and objectives (mission, vision, values, etc.) dictate the PLC. To address a specific need, certain factors and conditions come into play to influence its development: recognition, group moderator, shared leadership, and learning. What stands out is that instructional leaders shape their school into a PLC to encourage staff improvement (Hopkins, 2003). Successful high schools using the PLC approach foster learning via their institution's vision/objectives, as well as culture, structure, intellectual stimulation, individual support, and performance expectations (Sillins \& Milford, 2007). This leader uses the PLC as a means to stimulate their teachers' 
professional development (Robinson et al., 2008). This leader's top priority is to ensure that their school becomes a PLC (Hopkins, 2003; Sillins \& Mulford, 2007).

\section{Methodology}

\subsection{Participants and Data}

Individual interviews were conducted with 39 stakeholders to discuss their practices within a PLC in which they participated or moderated. As PLC members, these frontline expert informants (Marshall \& Rossman, 1989; Patton, 1990) possessed the most extensive knowledge of their respective PLCs (Gongla \& Rizzuto, 2001) and how they functioned. The method developed by Vermersch (2003) was used to help the participants explain their practices.

The participants included elementary and secondary school teachers, teaching consultants, principals, and vice-principals from the provinces of Québec and New Brunswick. The participants were also members of 24 PLCs whose goal was to improve student achievement. The issues covered were pedagogy, didactics, or the socioaffective aspects (a group of social skills concerning specific students identified by the teachers as requiring assistance to develop such skills as respect, empathy, anger management, among others).

The data was gathered during a semi-structured interview that lasted approximately an hour. The interviews were informal and, whilst organized around their practices in PLC in which they participated or moderated.

\subsection{Analysis}

The data were analyzed using Atlas.ti statistical software according to the theme-based qualitative analysis method developed by Paillé and Mucchielli (2003). Inter and intracoder reliability was verified (Miles \& Huberman, 2003) while taking into account the saturation theory by which the addition of new data adds nothing to the understanding of the phenomenon under study (Mucchielli, 1996).

\section{Results}

Within their respective PLCs, the members worked in either horizontal or vertical collaborations. Depending on the proposed objective, these PLCs were composed of various combinations of education stakeholders: teachers in the same field/grade level or in a variety of fields/levels, principals and vice-principals (large schools), remedial teachers, teaching consultants, social workers, psychologists, secretarial staff, support staff, technicians, etc. The principals were kept informed as to what went on in the different PLCs, whether through the recorded minutes of their meetings or during follow-ups with group leaders.

PLC activities consisted of meetings (once a week in some cases) where the teachers, supported by mentors or resource people, discussed issues with low-performing students, developed materials, and shared their experiences so as to identify effective pedagogical practices or to implement means to provide a safe, learning-oriented environment.

\subsection{Ensure the Physical Capital}

\subsubsection{Promote the PLC and Make Resources Available}

The principal must begin by promote a climate of collaboration through the PLC ethic: "My role is really to encourage collaborations between the members, whether it's about a specific issue or making it possible for people to discuss and share information" [PC2].

Individual proposals are not only heard but valued. Anyone within a school can take the initiative and set up a PLC: "That's an example to show that each person has spoken on the implementation of a new way of doing things" [P.4].

The school principal must also explain the how and the why of working in a PLC and see to it that the appropriate material, financial and scheduling resources are provided accordingly:

"... and just the fact of being able to make our job easier and accommodate us when they can. For example, they can provide resources like time or funds to help students progress. And the way they give us the time, because they free us as a team. So here again, we see that they encourage teamwork when they ask us 'Do you need more time?' and 'Ok, it will be allowed, but as a team'” [T.1]. 
Effective principals support this collaboration by responding to the necessary entailments of the PLC: “... to enlist that collaboration, to encourage productivity and discussion; it's like making sure everything runs smoothly, from logistics to organization” [P2].

\subsubsection{Maintain Focus on the Goals}

PLCs are governed by specific principles and objectives (mission, vision, values, etc.) that dictate the activities of its members. The PLC leader ensures that they focus on their ultimate goal which is student achievement:

"I would say that I'll get them to refocus when they get off track. And of course remind them of the goal, remind them that we want to help our students reach the desired level of competency by the end of the year. It's more that; refocus or regroup, I would say" [V-P.1].

These explanations and reminders are necessary to better guide the collaboration, without which the PLC members run the risk of missing the mark: "We have to have a prime directive in order to reach our goals; otherwise, we each go our separate ways and that doesn't work" [P.1]. In other words, these goals serve as the binding thread to improving our teaching in terms of the needs of the students. "It's important to share with the other teachers to better understand our students and to provide the best possible education for them" [T.1].

Contrary to the objectives which are constantly reminded, the vision requires no explanation due to the level of cohesion established among the members of the PLC: “Another side, an illustration of that was working with Mrs. X who shared the same vision of that. It was an extraordinary encounter: we didn't have to explain ourselves because we were on the same page" [V-P.1].

With reiterated objectives and clearly defined expectations, accountability becomes easier with PLCs:

"That's why I say that in supervising them and clearly expressing what is expected of them, I think we are able to come back to them and say 'Listen, we had an agreement, this is what I asked you to do, so now you have to move forward"' [P.1].

\subsection{Ensure the Human Capital}

\subsubsection{Work on the Perceptions}

To be successful in obtaining the desired results, principals must accentuate the importance of being proactive, not only on the practices but also on the perceptions, as the latter regulate the practices. In response to a comment made by a teacher regarding his feeling of ineffectiveness with regard to his students' motivation: "It's not like it used to be, the students are lazier and get involved less" [V-P.4], the principal saw this as an opportunity to emphasize to their teachers just how important their collective commitment was, despite the difficulties, so as to avoid the propagation of this feeling of losing control:

"My role is to constantly remind them why we are doing this. We do it for the students, even if they are different; it's not like it was in the 80s. I have to remain focused... Obviously, I have to be a motivator for my teachers so they'll stick to the plan right to the end" [V-P.4].

\subsubsection{Supervise and Empower}

In PLCs, different roles are assigned to the participating members. Some principals felt a responsibility to ensure that innovations be well integrated:

"We have to take advantage of this, bring in something new, stay up to date on all that. We must be able to stir things up, and once we have done that, we have to help them digest, accept little by little all of the elements of the new practices. You have to guide them through this process, be there, and not leave them to themselves" [P.4].

While this guidance may be necessary, sharing responsibilities within the PLC does remain one of its fundamental directives. Each member must actively participate in the smooth running of the teamwork:

"It's important that each member be able to contribute, for the benefit of the group. At the end of the day, I want them to say 'I had my say in the good functioning of the school'. That is what is important to me" [P.4].

In addition, each PLC member contributes to attaining the objectives: "I played a role in the good functioning of the school" [V-P.1]. Some stated that it was not a matter of sharing and distributing tasks among the members but rather that each member, at one time or another, becomes a leader:

"There is no specific role, but everyone must be a leader on some level, and they know it. Each person is an expert... I expect that you bring something to the table at those meetings and you expect the exact same thing 
from me" [V-P.1].

Some principals work on encouraging the autonomy and commitment of their PLC members:

“... learn to let them stand on their own two feet and then provide feedback and supervision. It's important to set your sights straight, like when someone feels demoralized... We can't always hold take their hand; there obviously comes a time when they have to focus by themselves and get to work" [P.1].

The tasks performed within the PLC are projects that not only unite but also involve the members. The work is produced by the team, takes form, evolves, and is achieved through the contribution of each member: "For me, the teamwork that I want and that I value is when we start a project or an idea, we work all together on the project and we see it through to the end" [V-P.3].

\subsubsection{Become a PLC leader}

Although moderating a PLC is the duty of one member who manages the schedules and follow-ups, adds items to the agenda, etc., principals do get involved by leading a few of the meetings: "My role at these meetings -I am not present at each one but at those for which I am responsible, then I'm the one who conducts the meeting and who draws up the agenda" [V-P.4]. In the eyes of the teachers, the involvement of their principal in their PLCs and the latter's knowledge of the issues they are working on is highly motivating: "I really appreciate their presence and that they are involved in the process with us. If we speak about a particular student, they know what is going on" [T.1].

By sharing their vision, the school principal acts as an agent of change that unites the teachers and helps them move forward. The year-end reviews conducted by some principals with their teachers enable them to determine whether the goals have been reached: "In June, when the teachers talk to me about their strengths... That's when I see whether they have grown or not, where they are headed, and the direction I want them to take” [P.1].

\subsection{Ensure the Social Capital}

\subsubsection{Establish Good Communication Guidelines}

To ensure the smooth running of the PLC, the appropriate communication guidelines must be established. Among the answers of the participants, we identified five such guidelines: speak for yourself, avoid value judgements, respect minority opinions, know how to resolve conflict, and conduct follow-ups.

The effective moderator/leader gets the members of the PLC to speak from their own experience: "We always try to use the 'I'; that's in our charter; it's one of our ten commandments, to always start with 'I'” [V-P.3]. In this regard, some groups insist on having what could be referred to as a voice of reason or collective conscience beacon, to avoid any possible divergence: "We also have a sort of voice of reason, someone in the room who can say 'I think that we're starting to deprecate'” [V-P.3].

The moderator also strives to take into account and respect minority opinions:

"When we form the committees, we always bear this in mind. It takes someone who is firmly established as the leader to go get what they, the members, have to say. Each person must feel that they have a voice" [V-P.2].

Resolving conflict is another important duty of the PLC leader: "As the moderator, they must be able to take command of the conversation and to often summarize the situation, identify who are the antagonists, and integrate someone inside their dyad so as to have a more balanced discussion" [V-P.3].

To optimize the length of the meetings, the leader is there to ensure the continuity of the projects from one meeting to the next and that the necessary documentation is available: "When you enter the room where the PLC is meeting, there is always one person in charge who asks, for example, 'Mr. $\mathrm{X}$, did you bring your student evaluations?'” [P.4].

\subsubsection{Work Organization}

Work in a PLC requires structure and a certain amount of diligence in terms of time and organization. The following depicts how a typical PLC meeting takes place, in this case involving distance course teachers and their principal. The meeting always proceeds in the same rigorous manner, namely, how things are going in their course, what are the challenges/achievements, and are there any technological developments which may be of help:

"Everyone has to be on time. We begin with a welcome. Each person speaks in turn, talks about how their course is doing, whether there are problems with a school or if there have been any good outcomes during the 
week" [T.5].

\subsubsection{Informal (Natural) Mutual Support}

There are different ways to organize the work within a PLC. The most common form of organization builds on the strengths of each member and each member takes on a task when the time comes. Although these tasks are performed informally, others may be more structured, while trying to avoid confining members within predefined roles:

"In fact, our agenda was laid out from the beginning and we divided up who would start, who would address which issue. So, in that respect, yes there was preparation and yes we did have a distribution of roles, but other than that... Of course, informally, things evolved over time... but then again, nothing was set in stone” [P1].

\subsubsection{Time}

Teamwork requires consultation and organization, which calls for more time than for individual work; however the time thought to be lost in the process is picked up in the long term because the developed tools are reinvested the following year: "So maybe we do lose time because we work on what we have developed, but they are of better quality. We don't have to rework them as much the following years" [EC2].

Working as a PLC helps members to decompartmentalize, avoid task duplication, and not waste time, a factor that often characterizes solitary activity:

"For me, in general, I find it much more efficient. I would say that no one is looking to reinvent the wheel. There is a lot of sharing going on, which in the end saves time and it's more productive" [T.1].

The education consultants stated that they saved time when working in a PLC because they could combine their strengths and move toward more extensive practices in a shorter amount of time:

"As a consultant, this teamwork really enables us to go further, to evolve toward different practices. Each member's opinion and practices change depending on who they are, so when we form a team and we share, it's really an interesting development tool" [EC 2].

\subsubsection{Task or Role Sharing}

To eliminate any ambiguity with regard to the roles, some PLCs decide divide the tasks among their members, while others emphasize the importance of considering the members' psychological/emotional, social, intellectual, and experiential capabilities before distributing responsibilities; in this view, skills may vary from one person to another and for some, may even be absent altogether:

"I think that everyone does not have the same responsibility, nor an equivalent one... We must recognize that some people are excellent in one area while some are not. And not everyone performs in a team setting and I don't think it's for everyone. Everyone should simply give the best that they have to offer" [P2].

In this sense, roles are predefined and individuals will often have a tendency to conform to what is expected of them. They must understand the roles and take them on to avoid conflict and ambiguity:

"We expect each member to not only fully understand their role but own this responsibility within the team. We also expect that they do not take on someone else's role. For example, the education consultant should not take on the role of teacher" [EC1].

In fact, clearly defining the roles enables the PLC members to avoid ambiguity, work overloads, underdevelopment, and conflict: "I think that before teamwork can begin, we should assign each person their task, assign a role for each person, and make it clear what is expected of each person before we start" [P1].

Several participants in our study stated that the PLC was a context where equality reigned. Members are encouraged to perform their tasks without having some members taking on more than the others. To do this: "the work must be distributed fairly" [T2]. Mutual and moral support is enormously valued and each member adds their own personal touch. Fairness is important so as not to overwork any one individual: "You have to be able to say 'that person has a lot more on their shoulders than do the others'” [T2].

The teachers in our study expressed their appreciation with regard to the sharing the work: "I think everyone has a role to play, especially in same-level consultations; everyone is important” [T4]. They insist that the work should be distributed evenly, except for the person officially designated as leader:

"Unless the role of leader is clearly established, in my opinion the roles should be equal and connected, depending on the strengths of each person... We can't do it all, be responsible for distributing all of the material for the others... So unless I know for sure that someone is the leader and it's clear, I expect that each person 
gets the same amount of work" [T4].

\subsubsection{The Impact of Experience and Mutual Trust}

While some advocated the equal distribution of responsibilities within the PLC, others mentioned that the assigned duties were guided by the person's experience, level of confidence they exerted and the amount of trust their colleagues had toward them. It is therefore not surprising that some people have more responsibilities and play a more important role because of the fact that others see them as mentors:

"I think the level of responsibility of each person depends on where they are at within the community... We could not evaluate everyone's contributions the same way. Not everybody contributes the same way; it should be done according to where you're at and what you have to bring to the table" [EC1].

Seasoned veterans and new teachers can both contribute significantly; some by their experience and others by their ideas: "The older ones who have more experience and the younger ones who have more ideas" [DC1]. However, the number of years of experience is not a factor: "Like I said, there are people who are not at the same level, and then you have people who've been teaching for twenty years and are still not comfortable in their work" [T4].

Social loafing. Because team results regard a group rather individuals, the phenomenon known as social loafing may be an issue within the PLC. To avoid possible conflicts, effective principals verify the involvement of each member. Certain situations may require that they intervene discretely with teachers who do not get involved to remind them of the basic principles of working in a PLC, which is to contribute to its advancement:

"Of course, I won't say to them 'I'm taking you off the team', but I will help the person decide whether or not they should remove themselves by saying to them 'Listen, if you want to come back next year or when you feel you are ready or when you have more time, the door is open to you'... Basically, I help them recognize that they did not do what was asked of them or what had been previously agreed upon by the community" [V-P.3].

In addition to saving time, the PLC enhances cohesion, which ultimately translates to tangible advantages for the team in reaching its goals, whether it be improving student achievement or improving security in the schoolyard: "I can tell you that there has been a vast improvement in terms of supervision in the schoolyard during recess; I feel that the students are even more safe" [P4].

Because it originates from the sharing of related issues and power, the PLC creates a bond among their members and instills a greater level of commitment:

"It enables us to create something, because often it's someone's idea that makes it possible for us to improve things. It puts us all on the same wavelength, it rallies us together. It's much better than a decision that comes from me that is applied to everyone, where no one feels concerned. So it makes it possible to get everyone involved and makes them accountable" [P1].

\section{Discussion}

This study addressed the practices taking place in PLCs composed of principals, vice principals, teachers, and other non-teaching personnel in two Canadian provinces (Québec and New Brunswick). The participants were either members or leaders of these PLCs.

The premise here that the work achieved in a PLC improves teacher professional development by enabling its members to improve their pedagogical practices (Dufour, 2003). This is undoubtedly an excellent model for professional development by peers; however, this specific support is first provided by the principal or by teacher-leaders who must implement the PLC and provide the necessary guidance as moderator, leader, and project organizer. We identified three mobilization practices within the PLCs, namely, to ensure the necessary physical, human, and social capital.

\subsection{Physical Capital}

The physical component is crucial for PLCs. The participants in our study stated that they do not only promote PLCs and explain the whys and wherefores, but are actually committed to obtaining and providing the necessary material, financial, and time resources to ensure a successful outcome.

While New Brunswick school districts allow for time during work hours for PLC activities, this type of organization has not yet been fully explored in Québec. In fact, New Brunswick allocates time during work hours for meetings with peers, a practice shared by several education systems to introduce reforms (Coburn \& Russell, 
2008; Schechter \& Atarchi, 2013).

\subsection{Human Capital}

Providing the human capital requires a consolidation of the teachers' knowledge, skills, and expertise. Some participants in our study stated that it was important to work on the perceptions in the event of a lack of focus or efficacy among the staff. Some principals nurtured their PLCs by easing them along little by little to facilitate the integration of change and help members become independent (stand on their own two feet).

\subsection{Social Capital}

The social capital is also indispensable in a PLC, as the group must maintain good relations at all times. This can be achieved when the group is well governed by clearly defined guidelines that encourage constructive communication, productive project organization, and smooth operations to prevent conflict.

Proper guidance by a resource person ensures the sustainability and strength of the PLC. In this view, sharing and support are crucial for the social capital, also referred to as the affective dimension (Savoie-Zajc et al., 2005; Schussler, 2003). This social component must be further investigated to shed light on how individuals create these connections to collaborate and how some PLCs come to develop this competence. This enables them to acquire knowledge and skills to grow professionally and, ultimately, to improve student's achievement.

\subsection{Limitations and Further Research}

It must be said that the work achieved in a PLC is not a panacea or magic formula to improve teaching (Hargreaves, 2003; Kennedy \& Smith, 2013; Dionne, Lemire, \& Savoie-Zajc, 2010). Choosing PLCs as the sole method of professional development does not take into account the idea of differentiation that is increasingly impressed upon teachers to apply directly in their classroom. Thus, other professional growth models must operate jointly with the PLC, as effective teacher supervision considers the sociodemographic and socioprofessional characteristics as well as how far the teachers are in their career.

Finally, in light of qualitative studies confirming that teachers welcome collaborations with their peers (Courneya, Pratt, \& Collins, 2008; Tschannen-Moran, 2009; Wahlstrom \& Louis, 2008), it would be of interest to examine reforms and practices that have been adopted. A longitudinal study would most certainly provide a greater understanding of the dynamics that result in the introduction and progression of PLCs and better define their mechanisms.

\section{References}

Anderson, J. B. (2008). Principal's Role and Public Primary School’s Effectiveness in Four Latin American Cities. The Elementary School Journal, 109, 36-60. http://dx.doi.org/10.1086/592366

Bogotch, I., Mirón, L., \& Biesta, G. (2007). Effective for What; Effective for Whom? Two Questions SESI Should Not Ignore. In T. Townsend (Ed.), International Handbook of Effectiveness and Improvement, Springer, Berlin, 93-110.

Boucher, L.-P., \& Jenkins, S. (2004). Un soutien au processus de transformation des pratiques au primaire. In L.-P. dans Boucher, \& M. L’Hostie (dir.), L'accompagnement en éducation, Un soutien au renouvellement des pratiques, Québec, PUQ, 83-106.

Bourhis, A., \& Tremblay, D. G. (2004). Les facteurs organisationnels de succès des communautés de pratique virtuelles. Québec: Cefrio. Collection Recherche et Études de cas.

Brassard, A., Cloutier, M., De Saedeleer, S., Corriveau, L., Fortin, R., Gélinas, A., \& Savoie-Zajc, L. (2004). Rapport à l'activité éducative et identité professionnelle chez les directeurs d'établissement des ordres d'enseignement préscolaire et primaire. Revue des sciences de l'éducation, 30, 487-508. http://dx.doi.org/10.7202/012079ar

Butler, D. L., Novak Lauscher, H., Jarvis-Selinger, S., \& Beckingham, B. (2004). Collaboration and Self-Regulation in Teachers’ Professional Development. Teaching and Teacher Education, 20, 435-455. http://dx.doi.org/10.1016/j.tate.2004.04.003

Caldwell (2007). The Maturing of Movement: Tracking Research, Policy and Practice. In T. Townsend (Ed.), International Handbook of Effectiveness and Improvement, Springer, Berlin, 307-324,

Charlier, É., Dejean, K., \& Donnay, J. (2004). Nouvelles postures de travail du chercheur en éducation... In Pelletier (Dir.) Accompagner les réformes et les innovations en éducation, L’Harmattan, Paris, 25-143. 
Clausen, K. W., Aquino, A. M., \& Wideman, R. (2009). Bridging the Real and Ideal: A Comparison between Learning Community Characteristics and a School-Based Case Study. Teaching and Teacher Education, 25, 444-452. http://dx.doi.org/10.1016/j.tate.2008.09.010

Coburn, C. E., \& Russell, J. L. (2008). District Policy and Teachers' Social Networks. Educational Evaluation and Policy Analysis, 30, 203-235. http://dx.doi.org/10.3102/0162373708321829

Coldren, A. F., \& Spillane, J. P. (2007). Making Connections to Teaching Practice: The Role of Boundary Practices in Instructional Leadership. Educational Policy, 21, 369-396. http://dx.doi.org/10.1177/0895904805284121

Courneya, C. A., Pratt, D. D., \& Collins, J. B. (2008). Through What Perspective Do We Judge the Teaching of Peers? Teaching and Teacher Education, 24, 69-79. http://dx.doi.org/10.1016/j.tate.2007.01.009

Cwikla, J. (2007). The Trials of a Poor Middle School Trying to Catch Up in Mathematics: Teacher's Communities of Practice and the Boundary Encounters. Education and Urban Society, 39, 554-583.

http://dx.doi.org/10.1177/0013124507302464

Deslauriers, C. (2008). Une route pavée d'encre et de mots. Viepédagogique, 147, 15-19.

Dionne, L. (2004). L'espace de médiation: Un lieu de réflexion sur les rôles et la posture du chercheur. L'Hostie \& Boucher (dir.), L’accompagnement en éducation, Qc, PUQ, 63-80.

Dionne, L., Lemyre, F., \& Savoie-Zajc, L. (2010). Vers une définition compréhensive de la communauté d'apprentissage (CA) comme dispositif de développement professionnel des enseignants. Revue des sciences de l'éducation, 36, 25-43. http://dx.doi.org/10.7202/043985ar

DuFour, R., Eaker, R., \& DuFour, R. (1998). Professional Learning Communities at Work: Best Practices for Enhancing Student Achievement. National Educational Service, Bloomington, IN: Association for Supervision and Curriculum De-velopment, Alexandria, ERIC Document Reproduction Service No. ED426472.

Fullan, M. (2000).The Return of Large-Scale Reform. Journal of Educational Change, 1, 5-27. http://dx.doi.org/10.1023/A:1010068703786

Fullan, M. (1993). The Complexity of the Change Process. In M. Fullan, (Ed.), Change Forces: Probing the Depth of Educational Reform. New York: The Falmer Press.

Giles, C., \& Hargreaves, H. (2006). The Sustainability of Innovative Schools as Learning Organizations and Professional Learning Communities during Standardized Reform. Educational Administration Quarterly, 42, 124-156. http://dx.doi.org/10.1023/A:1010068703786

Gongla, P., \& Rizzuto, C. R. (2001). Evolving Communities of Practice: IBM Global Services Experience. IBM Systems Journal, 40, 842-862. http://dx.doi.org/10.1147/sj.404.0842

Government of New Brunswick (1997) CHAPTER E-1.12 Education Act. http://www.gnb.ca/0062/pdf-acts/e-01-12.pdf

Hallinger, P. (2005). Instructional Leadership and the School Principal: A Passing Fancy That Refuses to Fade Away. Leadership and Policy in Schools, 4, 221-239http://dx.doi.org/10.1080/15700760500244793

Hallinger, P., \& Heck, R. H. (1996). Reassessing the Principal’s Role in School Effectiveness: A Review of Empirical Research, 1980-1995. Educational Administration Quarterly, 32, 5-44. http://dx.doi.org/10.1177/0013161X96032001002

Hildreth, \& Kimble (2004). Knowledge Networks: Innovation trough Communities of Practice. London: Idea Group Publishing.

Hopkins, D. (2003) Instructional Leadership and School Improvement. In A. Harris, C. Day, D. Hopkins, M. Hadfield, A. Hargreaves, \& C. Chapman (Eds.), Effective Leadership for School Improvement (pp. 55-71). London: Routledge Falmer.

Hord, S. M., \& Summers, W. A. (2008). Leading Professional Learning Communities: Voices from Research and Practice. Thousand Oaks, CA: Corwin.

Kennedy, S., \& Smith, J. (2013) The Relationship between School Collective Reflective Practice and Teacher Physiological Efficacy Sources. Teaching and Teacher Education, 29, 132-143. http://dx.doi.org/10.1016/j.tate.2012.09.003

Lafortune, L., \& Deaudelin, C. (2001). Accompagnement Socioconstructiviste, Qc, PUQ.

Lafortune, L., \& Martin, D. (2004). L’accompagnement : processus de coconstruction et culture pédagogique. L’Hostie \& Boucher (dir.), L’accompagnement en éducation, Qc, PUQ, 47-62.

Lave, L. (1988). Cognition in Practice: Mind, Mathematics and Culture in Everyday Life. Cambridge: Cambridge University Press. http://dx.doi.org/10.1017/CBO9780511609268

Leithwood, K. (2007). The Emotional Side of School Improvement: A Leadership Perspective. In T. Townsend (Ed.), The International Handbook on School Effectiveness and Improvement (pp. 615-634). Dordrecht: Springer. http://dx.doi.org/10.1007/978-1-4020-5747-2__34

Leithwood, K., \& Levin, B. (2005). Assessing School Leaders and Leadership Programme Effects on Pupil Learning. DfES Research Report 662, London: DfES. 
Leithwood, K., \& Louis, K. S. (1998). Organizational Learning in Schools: An Introduction. In K. Leithwood, \& K. S. Louis (Eds.), Organizational Learning in Schools (pp. 1-14). Lisse: Swets \& Zeitlinger.

Leithwood, K., Day, C., Sammons, P., Harris, A., \& Hopkins, D. (2006). Successful School Leadership: What It Is and How It Influences Pupil Learning. London: DfES and Nottingham, NCSL.

Leithwood, K., Louis, K. S., Anderson, S., \& Wahlstrom, K. (2004). How Leadership Influences Student Learning. http://www.wallacefoundation.org/NR/rdonlyres/E3BCCFA5-A88B-45D3-8E27B973732283C9/0/ReviewofResearchLear ningFromLeadership.pdf

Marshall, C., \& Rossman, G. B. (1989). Designing Qualitative Research. Newbury Park, CA: Sage.

Miles, M., \& Huberman, (2003). Analyse des données qualitatives. Bruxelles: De Boeck Université.

Ministère de l’Éducation, du Loisir et du Sport (2008). La formation à la gestion d'un établissement d'enseignement. Les orientations et les compétences professionnelles, Québec, Gouvernement du Québec.

Mitchell, C., \& Sackney, L. (2000). Profound Improvement: Building Capacity for a Learning Community. Lisse: Swets \& Zeitlinger.

Mucchielli, A. (1996). Dictionnaire des méthodes qualitatives en sciences humaines et sociales. Paris: Éditions Armand Collin.

Mullen, C. A., \& Hutinger, J. L. (2008). The Principal’s Role in Fostering Collaborative Learning Communities through Faculty Study Group Development. Theory into Practice, 47, 276-285. http://dx.doi.org/10.1080/00405840802329136

New Brunswick, Department of Education: NBDE (1999). Programme d’évaluation du personnel enseignant. http://www.gnb.ca/0000/publications/evalf/99327.pdf

New Brunswick, Department of Education: NBDE (2007). When Kids Come First. A Challenge to All New Brunswickers to Built Canada's Best Education System New Vision for Public Education in New Brunswick.

http://www.gnb.ca/0000/kidsfirst-f.asp

Newell Jones, K. (2006). Small Beginnings of a Community of Practice with a Global Focus.

Nolan, J. F., \& Hoover, L. A. (2008). Teacher Supervision and Evaluation: Theory into Practice (2nd ed.). New York: Wiley \& Sons.

Paillé, P., \& Muchielli, A. (2003). L'analyse qualitative en sciences humaines et sociales. Paris: Armand Colin.

Patton, D. L. (1990). Qualitative Evaluation and Research Methods (2nd ed.). Londre: Sage Publications.

Printy (2004). The Professional Impact of Communities of Practice. UCEA Review, 46, 2023.

Printy, S. M. (2008). Leadership for Teacher Learning: A Community of Practice Perspective. Educational Administration Quarterly, 44, 187-226. http://dx.doi.org/10.1177/0013161X07312958

Reynolds, D., Creemers, B., Stringfield, S., Teddlie, C., \& Schaffer, G. (2002). World Class Schools. International Perspectives on School Effectiveness. London: Routledge-Falmer.

Robinson, V. M. J., Lloyd, C. A., \& Rowe, K. J. (2008). The Impact of Leadership on Student Outcomes: An Analysis of the Differential Effects of Leadership Types. Educational Administration Quarterly, 44, 635-674. http://dx.doi.org/10.1177/0013161X08321509

Sackney, L. (2007). History of the School Effectiveness and Improvement Movement in Canada over the Past 25 Years. In T. Townsend (Ed.), International Handbook of School Effectiveness and Improvement (pp. 167-182). Berlin: Springer.

Savoie-Zajc, L. (2004). Les communautés de pratique des chercheurs et des enseignants. In G. Pelletier (Ed.), Accompagner les réformes et les innovations en éducation (pp. 211-213). Paris: L’Harmattan.

Savoie-Zajc, L., Rochon, S., \& Ruel, J. (2005). The Challenge of Supporting School Personnel in Professional Learning Communities: Two Action Research Studies. Annual Conference of the American Educational Research Association (AERA).

Schechter, C., \& Atarchi, L. (2013). The Meaning and Measure of Organizational Learning Mechanisms in Secondary Schools. Educational Administration Quarterly, Published Online. http://dx.doi.org/10.1177/0013161X13508772

Schussler, D. L. (2003). Schools as Learning Communities: Unpacking the Concept. Journal of School Leadership, 13, 498528

Senge, P. (1990). The Fifth Discipline: The Art and Practice of the Learning Organization. New York: Doubleday/Currency.

Senge, P., Cambron-McCabe, N., Lucas, T., Smith, B., Dutton, J., \& Kleiner, A. (2000). Schools That Work: A Fifth Discipline Fieldbook for Educators, Parents, and Everyone Who Cares about Education. New York: Doubleday.

Sillins, H., \& Mulford, B. (2007) Leadership and School Effectiveness and Improvement. D. Townend, (Ed.), International Handbook of School Effectiveness and Improvement (pp. 635-658). Berlin: Springer.

Spillane, J. P., Diamond, J. B., Walker, L. J., Halverson, R., \& Jita, L. (2001a). Urban School Leadership for Elementary Sci- 
ence Instruction: Identifying and Activating Resources in an Undervalued School Subject. Journal of Research in Science Teaching, 38, 918-940. http://dx.doi.org/10.1002/tea.1039

Spillane, J. P., Halverson, R., \& Diamond, J. B. (2001b). Investigating School Leadership Practice: A Distributed Perspective. Educational Researcher, 30, 23-28. http://dx.doi.org/10.3102/0013189X030003023

Tarakdjian, É. (2008) Évaluation des compétences professionnelles en collégialité. Vie Pédagogique, 147, 52-55.

Tremblay (2005). Les communautés de pratique: Quels sont les facteurs de succès? Revue internationale sur le travail et la société, Octobre 2005.

Tschannen-Moran, M. (2009). Fostering Teacher Professionalism: The Role of Professional Orientation and Trust. Educational Administration Quarterly, 45, 217-247. http://dx.doi.org/10.1177/0013161X08330501

Vermersch, P. (2003). L'entretien d'explicitation. Issy-les-Moulineaux: ESF Éditeur.

Vescio, V., Ross, D., \& Adams, A. (2008). A Review of Research on the Impact of Professional Learning Communities on Teaching Practice and Student Learning. Teaching and Teacher Education, 24, 80-91. http://dx.doi.org/10.1016/j.tate.2007.01.004

Wahlstrom, K. L. (2004). Leadership and Learning: What These Articles Tell Us. Educational Administration Quarterly, 44, 593-597. http://dx.doi.org/10.1177/0013161X08321494

Wahlstrom, K. L., \& Louis, K. S. (2008). How Teachers Experience Principal Leadership: The Roles of Professional Community, Trust, Efficacy, and Shared Responsibility. Educational Administration Quarterly, 44, 458-495. http://dx.doi.org/10.1177/0013161X08321502

Waters, T., Marzano, R. J., \& McNulty, B. (2003). Balanced Leadership: What 30 Years of Research Tells Us about the Effect of Leadership on Student Achievement. Aurora, CO: Mid-Continent Research for Education and Learning. http://www.mcrel.org/

Webb, R. (2005). Leading Teaching and Learning in the Primary School from “Educative Leadership” to "Pedagogical Leadership”. Educational Management Administration \& Leadership, 33, 69-91. http://dx.doi.org/10.1177/1741143205048175

Wenger, E. (1998) Communities of Practice: Learning, Meaning and Identity. New York: Cambridge University Press. http://dx.doi.org/10.1017/CBO9780511803932 
Scientific Research Publishing (SCIRP) is one of the largest Open Access journal publishers. It is currently publishing more than 200 open access, online, peer-reviewed journals covering a wide range of academic disciplines. SCIRP serves the worldwide academic communities and contributes to the progress and application of science with its publication.

Other selected journals from SCIRP are listed as below. Submit your manuscript to us via either submit@scirp.org or Online Submission Portal.
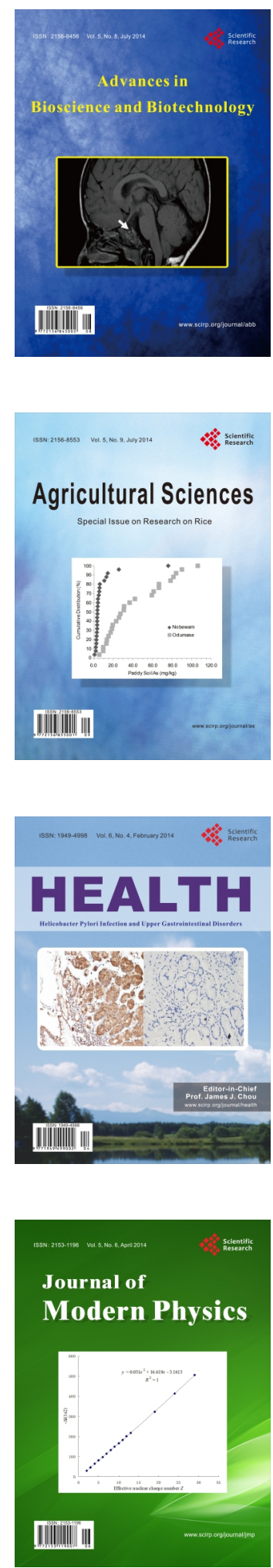
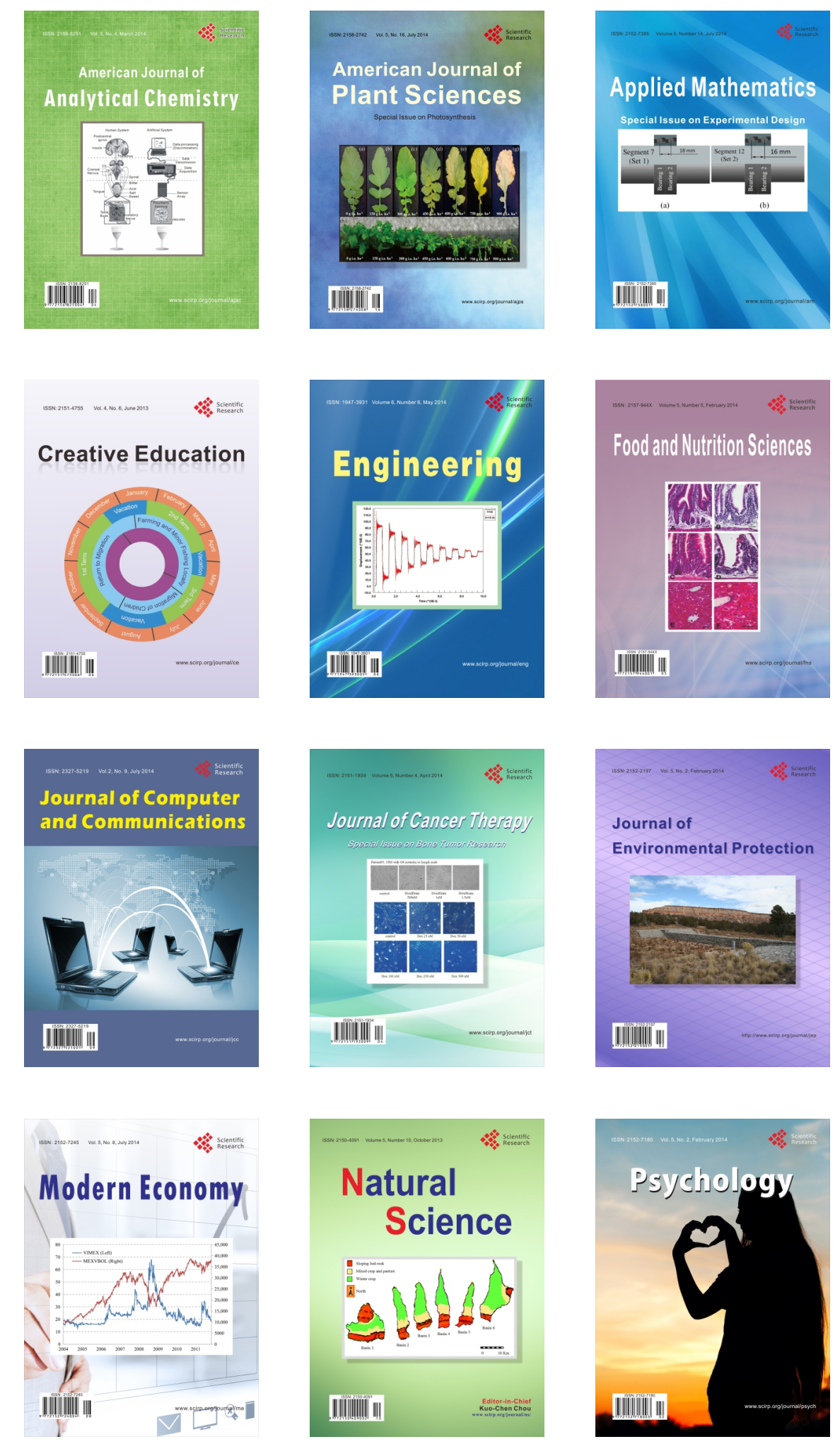